\title{
KEARIFAN LOKAL TINGKEPAN: KAJIAN PENDIDIKAN ANAK DALAM ISLAM
}

\author{
H. Moh. Rifai * \\ Hartuti **
}

\begin{abstract}
Children are not only endearment but also the determinant for afterlife happiness. In addition, they are successors of the former generation, a family's pride and evidence when humans are on the judgement day of yaumulmakhsyar. Such claims are available on holly scriptures including Al Quran. Since children are so highly valued, every single mother hopes to raise excellent children. In such perspective, pregnancy and child birth become among life cycles most paid attention to. A ritual for such event, tingkepan, is therefore, usually very well arranged to do. Parents, however, are advised to be well informed about the ritual to find bless rather than sins. They are to select values good for themselves as well as for their young such as through prayers in accordance with Islamic teaching and Javanese local wisdom. Both, Islamic teaching and Javanese local wisdom have been the worldview of Javanese ancestors who are faithful to Lord God.
\end{abstract}

Key words: Tingkepan, Culture, Islam

\begin{abstract}
Abstrak
Anak adalah perhiasan kehidupan dunia bahkan menjadi penentu kebahagiaan di akhirat. Hal ini menurut sebagaian keterangan dari ajaran agama yang diyakini kebenaranya seperti penjelasan dalam kitab suci Al Quran, juga sebagai penyambung generasi serta kebanggaan seseorang dalam keluarga yang kelak akan menjadikan bukti ketika manusia diadili oleh Allah Yang Maha Adil di yaumul makhsyar nanti, manusia itu selamat atau tidak dalam timbangan keadilan oleh Allah, anak ikut menentukanya karena anak adalah amanah dari Allah, oleh itu tidak ada orangtua khususnya ibu yang tidak mendambakan lahirnya generasi yang unggul dari dalam rahimnya. Karena itu proses kehamilan sampai melahirkan menjadi suatu proses yang sangat mereka perhatikan dalam rangka mewujudkan keinginan mereka (maksudnya bermeditasi) kepada Allah. Bahkan segala bentuk rangkaian upacara telah mereka siapkan sejak dini. Namun terkadang harapan tersebut akan berbuah dosa jika mereka tidak sanggup memilah dan memilih mana yang bermanfaat
\end{abstract}

* H. Moh. Rifai adalah Dosen Program Studi PGSD FIP IKIP PGRI Madiun dan Kandidat Doktor Universitas Merdeka Malang

** Hartuti adalah Mahasiswa Program Studi PGSD FIP IKIP PGRI Madiun 
bagi orangtua dan bagi calon jabang bayi yang kelak akan dilahirkan yang tujuanya guna mempengaruhi proses kembang serta tumbuhnya janin dengan perantaraan doa-doa yang sesuai dengan tradisi Islam dan adat jawa (kearifan lokal) yang menjadi saripati cara hidup leluhur yang penuh dengan pendekatan diri kepada Tuhan Yang Maha Kuasa.

Kata Kunci: Tingkepan, Budaya, Islam

\section{A. Pendahuluan}

Anak adalah anugerah terindah yang diberikan Allah, sebagai satu amanah yang harus dijaga tumbuh dan berkembangnya dengan baik. Kehadiran anak bagi orangtua, terlebih anak pertama mampu membawa dan menambah keharmonisan hubungan dalam keluarga merupakan harapan besar dari setiap hal yang dilakukan oleh orangtua demi menyambut kelahiran buah hatinya. Untuk itu orangtua seringkali melakukan berbagai upaya agar anak yang dilahirkan nantinya memperoleh kemudahan mulai dari proses kehamilan sampai kelahiran. Tidak jarang upaya yang dilakukan mereka terkesan "asal manut" pada orang-orang yang dianggap lebih tua atau lebih pandai, tanpa memahami lebih dalam makna dan tujuan tersebut. Bahkan seringkali hal itu justru mengarah pada kesesatankesesatan yang jelas-jelas dibenci oleh Allah. Diperlukan ketelitian dalam memilah dan memilih mana yang tepat untuk dilakukan bersandar pada ajaran Al Quran dan As Sunnah.

Kehadiran anak yang masih dalam kandungan sudah seharusnya menjadi perhatian khusus bagi calon orangtua, khususnya ibu. Berdasarkan segi kesehatan, calon ibu senantiasa dengan sabar memeriksakan kandungannya ke dokter secara periodik agar kesehatan bayinya terjaga. Secara psikis, emosional dan watak seorang ibu pun dapat ditularkan melalui perilaku seorang ibu selama mengandung dan mengasuh. Apa yang ibu dengarkan atau bacakan kepada bayi dalam kandungan, akan didengar pula oleh sang bayi. Menurut hasil penelitian, ketika seorang ibu yang mengandung memiliki perasaan ingin marah-marah, ada potensi sang anak kelak saat besar nanti akan memiliki penyakit jantung. Tidak cukup disitu, berbagai rangkaian ritualitas pada bulan tertentu pun disiapkan demi membangaun sebuah keyakinan tentang perilaku baik sang bayi di masa yang akan datang.

Di beberapa daerah di Indonesia, proses kehamilan mendapat perhatian tersendiri bagi masyarakat setempat. Harapan-harapan muncul terhadap bayi dalam kandungan, agar mampu menjadi generasi yang handal dikemudian hari. Untuk itu, dilaksanakan beberapa tradisi yang dirasa mampu mewujudkan keinginan mereka terhadap anak tersebut. Diantara tradisi tersebut adalah upacara neloni, mitoni/tingkepan. Neloni sendiri berasal dari kata telu yang artinya tiga. Sedangkan mitoni berasal dari kata pitu yang artinya tujuh. Hal ini dimaksudkan bahwa neloni atau pun mitoni/tingkepan adalah ritual yang dilaksanakan pada saat bayi menginjak usia tiga atau tujuh bulan dalam kandungan. 
Kajian tulisan ini membedah tradisi-tradisi yang telah membudaya di masyarakat, khususnya menyangkut ritual neloni, mitoni atau tingkepan. Tradisi tersebut merupakan upaya orangtua, khususnya para calon ibu, agar harapan mereka yang mulia terhadap anaknya kelak benat-benar terwujud.

\section{B. Pembahasan}

\section{Sejarah Tingkepan}

Tingkepan menurut cerita yang berkembang di masyarakat secara individu ke individu yang lain, dari mulut ke mulut, memang sudah ada semenjak jaman dahulu. Menurut cerita lisan yang mahsyur diperoleh, konon ada sepasang suami istri yang memiliki anak sebanyak sembilan, namun tidak sampai menginjak dewasa anak itu meninggal satu demi satu hingga habis. Berbagai ikhtiar telah diupayakan oleh keluarga itu. Mulai minta jasa secara spiritual dari orang pintar (dukun, paranormal, orang sakti) menurut kepercayaan orang Jawa, hingga para pandita, namun belum membuahkan hasil. Akhirnya pasangan ini memberanikan diri untuk menghadap Kanjeng Sinuwun Jayabaya (Raja Kerajaan Kadiri yang terkenal sakti dan bijak punya kearifan secara sepiritual).

Jayabaya akhirnya menasihati kepada pasangan itu agar melakukan ritual. Namun sebagai syarat pokok, mereka harus rajin manyembah secara khusyu' kepada Gusti Allah, selalu berbuat yang baik dan suka menolong serta welas asih kepada sesama. Selain itu, mereka harus menyucikan diri dengan cara mandi suci memakai air yang berasal dari tujuh sumber. Kemudian berpasrah diri lahir batin serta dibarengi permohonan kepada Gusti Allah, apa yang menjadi kehendak mereka, terutama untuk kesehatan dan kesejahteraan si bayi. Supaya mendapatkan berkah dari Gusti Allah, sebaiknya diadakan sesaji (bersedekah dengan membuat makanan tertentu guna menambah keyakinan makbul dalam berdoa kepada Allah/ untuk penguat doa dan penolak bala').

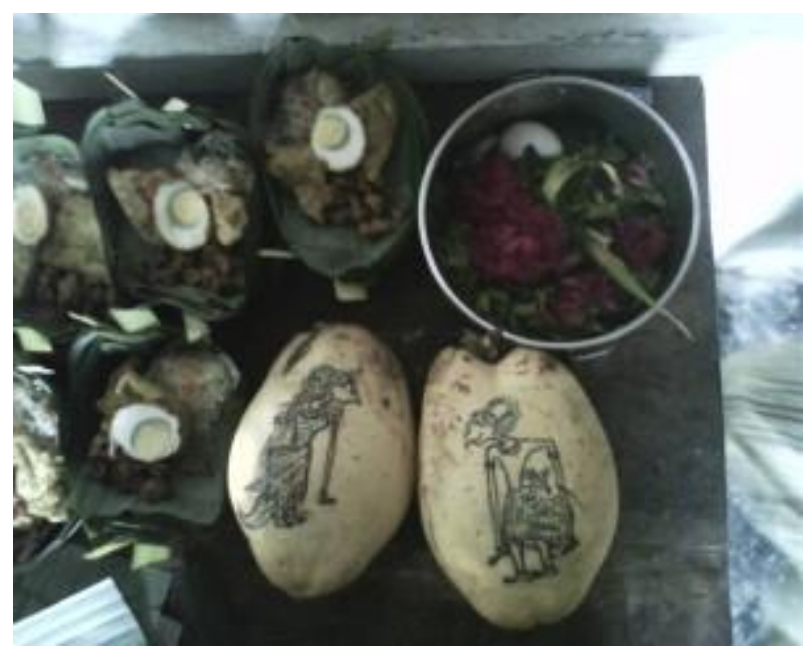

Gambar 1 Contoh Membuat Makanan Tertentu Seperti Takir Plontang, Kembang Setaman, dan Kelapa Muda

Setelah melakukan ritual yag dianjurkan oleh Raja Jayabaya, rupanya Gusti Kang Mubahing Dumadi yaitu Gusti Allah mengabulkan permintaan 
mereka. Ki Sedya dan Niken Satingkeb mendapatkan momongan yang sehat dan berumur panjang. Untuk mengingat nama Niken Satingkeb, upacara mitoni ini juga disebut tingkepan. Dengan harapan mendapatkan kemudahan dan tidak ada halangan apapun pada saat hamil, melahirkan, hingga anak menjadi dewasa. Atas dasar inilah akhirnya hingga kini ritual tingkepan diadakan pada saat bayi berumur tujuh bulan di dalam kandungan sang ibu.

Menurut tradisi Islam klasik yang didasari dengan adat Jawa Islam Kuno, ritual tingkepan yang sederhana dengan acara mengundang sanak kerabat guna berdoa bersama dengan cara membaca surat tujuh yang ada dalam Al Quran, yakni: Surat Yaasiin, Surat Yusuf, Surat Maryam, Surat Tabarok, Surat Arrohman, Surat Al Waqi'ah, dan Surat Luqman. Secara adat ritual ini sudah memenuhi syarat. Sedangkan tata cara yang lengkap biasanya masih dilakukan di kraton-kraton dan masyarakat Jawa yang masih kuat memegang tradisi.

Persinggungan antara Jawa dan Islam menjadikan dua entitas kebudayaan adiluhung ini menjadi berbeda. Dua entitas kebudayaan ini tidak bisa dilihat secara hitam putih. Lebih dominan mana antara Jawa dan Islam? Pertanyaan ini menjadi tidak penting untuk dijawab. Karena batas-batas kebudayaan antara Islam dan Jawa sudah semakin kabur. Pertalian dan silang sengkarut pemahaman antara keislaman dan kejawaan (kejawen) inilah yang menuntun berbagai peneliti untuk serius melihat batas-batas pembiasan antara Islam dan Jawa. Namun hingga kini batas-batas itu tidak pernah bisa ditemukan, kecuali ada beberapa orang yang memiliki keyakinan beda tentang ritual tingkepan dianggap bertentangan dengan Sunnah Rosullulloh dan suatu perbuatan khurofat dan bagian dari bid'ah.

\section{a. Landasan Historis}

Tradisi tujuh bulanan atau tingkepan atau disebut juga mitoni yaitu upacara tradisional selamatan terhadap bayi yang masih dalam kandungan yang sudah berumur tujuh bulan. Tradisi ini berawal ketika pemerintahan Prabu Jayabaya. Pada waktu itu ada seorang wanita bernama Niken Satingkeb bersuami seorang pemuda bernama Sadiya. Keluarga ini telah melahirkan anak sembilan kali, namun satu pun tidak ada yang hidup. Karena itu, keduanya segera menghadap raja Kediri, yaitu Prabu Widayaka (Jayabaya). Oleh sang raja, keluarga tersebut disarankan agar menjalankan tiga hal, yaitu: Setiap Hari Rabu dan Sabtu, pukul 17.00, diminta mandi menggunakan batok kelapa, sambil mengucap mantera: "Hong Hyang Hyanging amarta martini sinartan huma, hananingsun hiya hananing jatiwasesa, wisesaning Hyang iya wisesaningsun. Ingsun pudya sampurna dadi manungsa".

Inti mantera tersebut adalah permohonan kesehatan kepada Allah tapi dengan Bahasa Jawa Kuno. Setelah mandi lalu berganti pakaian yang bersih, cara berpakaian dengan cara menggembol kelapa gading yang dihiasi Sanghyang Kamajaya dan Kamaratih atau Sanghyang Wisnu dan Dewi Sri, lalu di-brojol-kan ke bawah kelapa muda tersebut, diikat menggunakan daun tebu tulak (hitam dan putih) selembar. Setelah kelapa gading tadi di-brojol-kan, lalu diputuskan menggunakan sebilah keris oleh suaminya kalau cara islam mengilustrasikan kelapa gading tersebut dengan mengharapkan jabang bayi yang akan lahir 
hendaknya seperti: kalau laki-laki menyerupai Nabi yusuf, kalau perempuan menyerupai Siti Yulaikhah.

Ketiga hal di atas, tampaknya yang menjadi dasar masyarakat Jawa menjalankan tradisi selamatan tingkepan sampai sekarang. Sejak saat itu, ternyata Niken Satingkeb dapat hamil dan anaknya hidup. Hal ini merupakan lukisan bahwa orang yang ingin mempunyai anak, perlu laku kesucian atau kebersihan (meditasi dengan kesungguhan). Niken Satingkeb sebagai wadah harus suci, tidak boleh ternoda, karenanya harus dibersihkan dengan mandi keramas. Akhirnya sejak saat itu apabila ada orang hamil, apalagi hamil pertama dilakukan tingkepan atau mitoni. Tradisi ini merupakan langkah permohonan dalam bentuk selamatan.

Batas tujuh bulan sebenarnya merupakan simbol budi pekerti agar hubungan suami istri tidak lagi dilakukan, agar anak yang akan lahir berjalan baik. Istilah methuk (menjemput) dalam tradisi Jawa, dapat dilakukan sebelum bayi berumur tujuh bulan. Ini menunjukkan sikap hati-hati orang Jawa dalam menjalankan kewajiban luhur. Itulah sebabnya bayi berumur tujuh bulan harus disertai laku prihatin (semedi spiritual, tirakatan). Pada saat ini, keadaan ibu hamil telah seperti "sapta kukila warsa", artinya burung yang kehujanan. Burung tersebut tampak lelah, kurang berdaya, dan tak bisa terbang kemana-mana, karenanya yang paling mujarab ialah berdoa agar bayinya lahir selamat.

Beberapa pantangan yang patut dicatat oleh ibu hamil maupun suaminya, juga mengarah pada budi pekerti leluhur adat Jawa Kuno, yakni seorang ibu hamil dilarang makan buah yang melintang (misalnya buah kepel), dimaksudkan agar posisi bayi di perut tak melintang. Jika posisi melintang akan menyulitkan kelahiran kelak. Hal ini sebenarnya ada kaitannya dengan kesehatan, karena buah kepel sebenarnya panas jika dimakan, sehingga bila terlalu banyak akan berakibat pula pada keadaan bayi. Orang hamil, misalkan tidak boleh duduk di depan pintu dan di lumpang tempat menumbuk padi, sebenarnya memuat nilai etika Jawa, yakni agar sikap dan watak ibu hamil tak dipandang tidak sopan, karena posisi duduk demikian juga akan memalukan dan tidak enak dipandang.

Seorang suami yang dilarang menyembelih hewan, sebenarnya terkandung makna budi pekerti agar tidak menganiaya makhluk lain. penganiayaan juga merupakan tindakan yang tak baik. Di samping itu, lalu ada kata-kata "ora ilok" kalau meyembelih hewan, ini dimaksudkan agar bayi yang akan lahir tak cacat. Watak dan perilaku yang dilarang ini merupakan aspek preventif agar suami lebih berhati-hati. Di samping itu, baik suami maupun ibu hamil diharapkan tidak mencacat atau membatin orang-orang yang cacat, agar bayinya tidak cacat, adalah langkah hati-hati. Perilaku ini merupakan upaya agar pasangan tersebut tidak semena-mena kepada orang lain yang cacat (kalau menurut Islam menggunjing, memaki, menghina ciptaan Allah itu hukumnya haram) termasuk akhlak yang tercela.

Proses selamatan mitoni dilakukan di kebun kanan kiri rumah pada suatu krobongan. Krobongan adalah bilik yang terbuat dari kepang (anyaman bambu) dan pintunya menghadap ke timur, dihiasi dengan tumbuh-tumbuhan. Krobongan adalah lambang dunia, yaitu bahwa ibu hamil dan suami ketika melahirkan anak nanti harus menghadapi tantangan berat. Kelahiran anak nanti ibarat memasuki sebuah hutan (pasren). Adapun maksud pintu krobongan menghadap ke timur, 
dapat dikaitkan dengan asal kata timur dari bahasa Jawa Wetan (wiwitan). Artinya timur adalah permulaan hidup (sangkan paraning dumadi)menurut pandangan Islam bahwa hidup adalah aturan orang yang ingin hidup harus mengikuti aturan syariat Islam dan kehidupan harus diwarnai dengan perjuangan. Hidup itu adalah perjuangan, berusaha merubah nasibnya sendiri, dan tidak boleh pasrah tanpa adanya ikhtiar.

\section{b. Kandungan Filosofis}

Berbagai simbol tindakan dan beraneka macam makanan sebagai pelengkap ritual tingkepan/mitoni memang tampak bahwa masyarakat Jawa memiliki harapan-harapan keselamatan. Masyarakat Jawa menganggap mitoni sebagai ritual yang patut diperhatikan secara khusus. Dengan demikian dapat dikatakan bahwa makna dan fungsi kultural selamatan mitoni adalah: (1) untuk mewariskan tradisi leluhur, agar tidak kesiku (mendapatkan marabahaya); dan (2) untuk menjaga keseimbangan, keselarasan, kebahagiaan, dan keselamatan (slamet, ora ono apo-apo), maksudnya setelah bisa bersinergi dengan alam, kehidupan yaitu kondisi aman tenteram tanpa gangguan makhluk lain atau alam sekitar. Selain itu tradisi tujuh bulanan (tingkepan/mitoni) menunjukkan karakter masyarakat Jawa yang telah mengakar dengan budaya saling gotong-royong, belas kasih, dan kekeluargaan.

Hakikatnya tradisi ini adalah memohon keselamatan kepada Tuhan Yang Maha kuasa, sebagaimana ungkapan: "jabang bayi lahir sageto wilujeng selamet ampun enten alangan sak tunggal penopo". Anak yang dikandung akan terlahir dengan gangsar (mudah), sehat, selamat, fisik yang sempurna, tidak ada gangguan apa-apa. Hal ini sebenarnya menggambarkan budi pekerti Jawa yang selalu memproses diri melalui tazkiyatun nafsi (penyucian diri) untuk memohon kepada yang Maha Kuasa. Artinya wujud pengabdian diri kepada Tuhan Yang Maha Kuasa.

\section{Tata Cara Mitoni / Tingkepan}

Mitoni atau selamatan tujuh bulanan, dilakukan setelah kehamilan seorang ibu genap usia 7 bulan atau lebih. Dilaksanakan tidak boleh kurang dari 7 bulan, sekalipun kurang sehari.
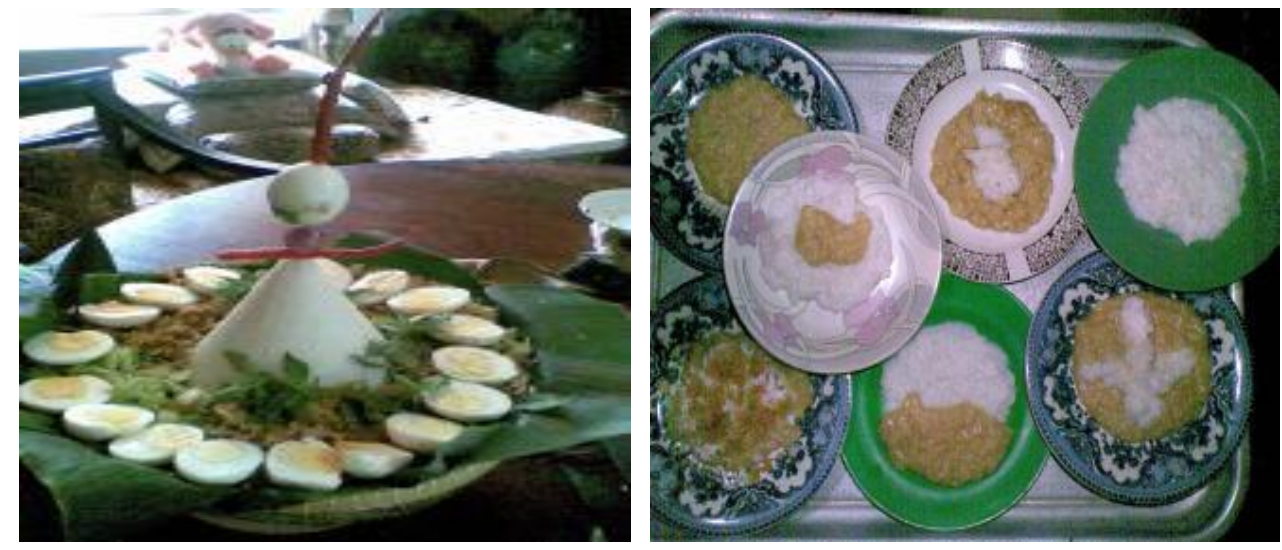

Gambar 2 Ubo Rampe Mitoni/Tingkepan (Selamatan Tujuh Bulanan) 
Belum ada neptu atau weton (hari masehi + hari Jawa) yang dijadikan patokan pelaksnaan, yang penting ambil hari selasa atau sabtu. Tujuan mitoni atau tingkepan agar supaya ibu dan janin selalu dijaga dalam kesejahteraan dan keselamatan (wilujeng, santosa, jatmika, rahayu). Adapun aneka macam makanan yang disediakan persyaratannya sebagai berikut:

a. Bubur 7 macam: (1) bubur merah; (2) bubur putih; (3) merah ditumpangi putih; (4) putih ditumpangi merah; (5) putih disilang merah; (6) merah disilang putih; dan (7) baro-baro (bubur putih diatasnya dikasih parutan kelapa dan sisiran gula jawa);

b. Gudangan Mateng (sayurnya direbus): bahan sayur 7 macam, harus ada kangkung dan kacang. Kangkung dan kacang panjang jangan dipotongpotong, dibiarkan panjang saja. Semua sayuran direbus. Bumbu gudangannya pedas;

c. Nasi Megono: Nasi dicampur bumbu gudangan pedes lalu dikukus;

d. Jajan Pasar: biasanya berisi 7 macam makanan jajanan pasar tradisional;

e. Rujak: bumbunya pedas dengan 7 macam buah-buahan;

f. Ampyang: ampyang kacang, ampyang wijen (7 macam ampyang). Apabila kesulitan mendapatkan 7 macam ampyang, boleh sedapatnya saja;

g. Aneka Ragam Kolo: Kolo kependem (kacang tanah, singkong, talas), kolo gumantung (pepaya), kolo merambat (ubi/ketela rambat); kacang tanah, singkong, talas, ketela, pepaya. direbus kecuali pepaya. Pepaya yang sudah masak. Masing-masing jenis kolo tidak harus semua, tetapi bisa dipilih salah satu saja. Misalnya kolo kependhem; ambil saja salah satu misalnya kacang tanah. Jika kesulitan mencari kolo yang lain; yang penting ada dua macam kolo: yakni cangelo; kacang tanah dan ketela (ubi jalar);

h. Ketan: dikukus lalu dibikin bulatan sebesar bola bekel (diameter 3-4 cm); warna putih, merah, hijau, coklat, kuning;

i. Tumpeng nasi putih: kira-kira cukup untuk makan 7 atau 11, atau 17 orang.

j. $\quad$ Telur: telur ayam 7 butir;

k. Pisang: pisang raja dan pisang raja pulut masing-masing satu lirang/sisir.

1. Tumpeng tujuh macam warna: tumpeng dibuat kecil-kecil dengan warna yang berbeda-beda. Bahan nasi biasa yang diwarnai.

Tata cara menyiapkan makanan yakni:

a. Tumpeng ditaruh di atas kalo (saringan santan yang baru). Bawahnya tumpeng dialasi daun pisang. Di bawah kalo dialasi cobek agar kalo tidak ngglimpang (jatuh miring). Sisa potongan daun pisang diletakkan di antara cobek dan pantat kalo. Sayur 7 macam direbus diletakkan mengelilingi tumpeng, letakkan bumbu gudangannya melingkari tumpeng juga. Telur ayam (boleh ayam kampung atau ayam petelur) jumlahnya 7 butir, direbus lalu dikupas, diletakkan mengelilingi tumpeng. Masing-masing telur boleh di belah jadi dua. Pucuk tumpeng dikasih sate yang berisi: cabe merah, bawang merah, telur utuh dikupas kulitnya, cabe merah besar, tancapkan vertikal (urutan ini dari bawah ke atas, Gambar 2); 
b. Tusuk satenya dari bambu, posisi berdiri di atas pucuk tumpeng, urutan dari bawah: cabe merah besar posisi horisontal, bawang merah dikupas, telur kupas utuh, bawang merah lagi, paling atas cabe merah besar posisi vertikal;

c. Pisang, jajan pasar, 7 macam kolo, dan 7 macam ampyang ditata dalam satu wadah tersendiri, namanya tambir atau tampah tanpa bingkai yang lebar. Tambirnya juga yang baru, jangan bekas. Tampah "pantatnya" rata datar, sedangkan tambir pantatnya sedikit agak cembung;

d. Tumpeng tujuh macam warna ukuran mini, ditaruh mengelilingi tumpeng besar. Boleh diletakkan di atas sayuran yang mengelilingi tumpeng besar;

e. Setelah ubo rampe semua selesai disiapkan, maka dimulailah berdoa. Doa boleh dengan tata cara atau agama masing-masing. Inilah fleksibilitas dan toleransi dalam ajaran Jawa.

Berikut ini contoh doa menurut tradisi Jawa yang diucapkan oleh orang tua jabang bayi (ayah dan ibu): "Niat ingsun nylameti jabang bayi, supaya kalis ing rubeda, nir ing sambikala, saka kersaning Gusti Allah. Dadiyo bocah kang bisa mikul dhuwur mendhem jero wong tuwa, migunani marang sesama, ambeg utama, yen lanang kadya Raden Komajaya, yen wadon kadya Dewi Komaratih. kabeh saka kersaning Gusti Allah". Apabila orangtua beragama Islam, setelah doa secara tradisi, lalu bacakan Surat Maryam atau Surat Yusuf.

Pilih diantara keduanya sesuai keinginan hati nurani. Jika feeling orangtua ingin membaca Surat Maryam, biasanya jabang bayi lahir perempuan. Bila yang dibaca Surat Yusuf, biasanya jabang bayi lahir laki-laki. Dalam tradisi Jawa, yang membuat bumbu rujak dilakukan oleh ibu jabang bayi. Jika bumbunya rasanya asin, biasanya jabang bayi lahir perempuan. Bila tidak kasinen (kebanyakan garam), biasanya lahir laki-laki.

\section{Upacara adat Jawa yang bernama Tingkepan atau Mitoni}

Upacara tingkepan disebut juga mitoni berasal dari kata pitu yang artinya tujuh, sehingga upacara mitoni dilakukan pada saat usia kehamilan tujuh bulan, dan pada kehamilan pertama. Dalam pelaksanaan upacara tingkepan, ibu yang sedang hamil tujuh bulan dimandikan dengan air kembang setaman, disertai dengan doa-doa khusus.

\section{a. Tata Cara Pelaksanaan Upacara Tingkepan}

Siraman dilakukan oleh sesepuh sebanyak tujuh orang. Bermakna mohon doa restu, supaya suci lahir dan batin. Setelah upacara siraman selesai, air kendi tujuh mata air dipergunakan untuk mencuci muka, setelah air dalam kendi habis, kendi dipecah. Memasukkan telur ayam kampung ke dalam kain (sarung) calon ibu oleh suami melalui perut sampai pecah, hal ini merupakan simbul harapan supaya bayi lahir dengan lancar, tanpa suatu halangan.

Berganti nyamping sebanyak tujuh kali secara bergantian, disertai kain putih. Kain putih sebagai dasar pakaian pertama, yang melambangkan bahwa bayi yang akan dilahirkan adalah suci dan mendapatkan berkah dari Tuhan. Diiringi dengan pertanyaan sudah "pantas apa belum", sampai ganti enam kali dijawab oleh ibu-ibu yang hadir "belum pantas." Sampai yang terakhir ke tujuh kali dengan kain sederhana di jawab "pantes". Adapun nyamping yang dipakaikan 
secara urut dan bergantian berjumlah tujuh dan diakhiri dengan motif yang paling sederhana sebagai berikut:
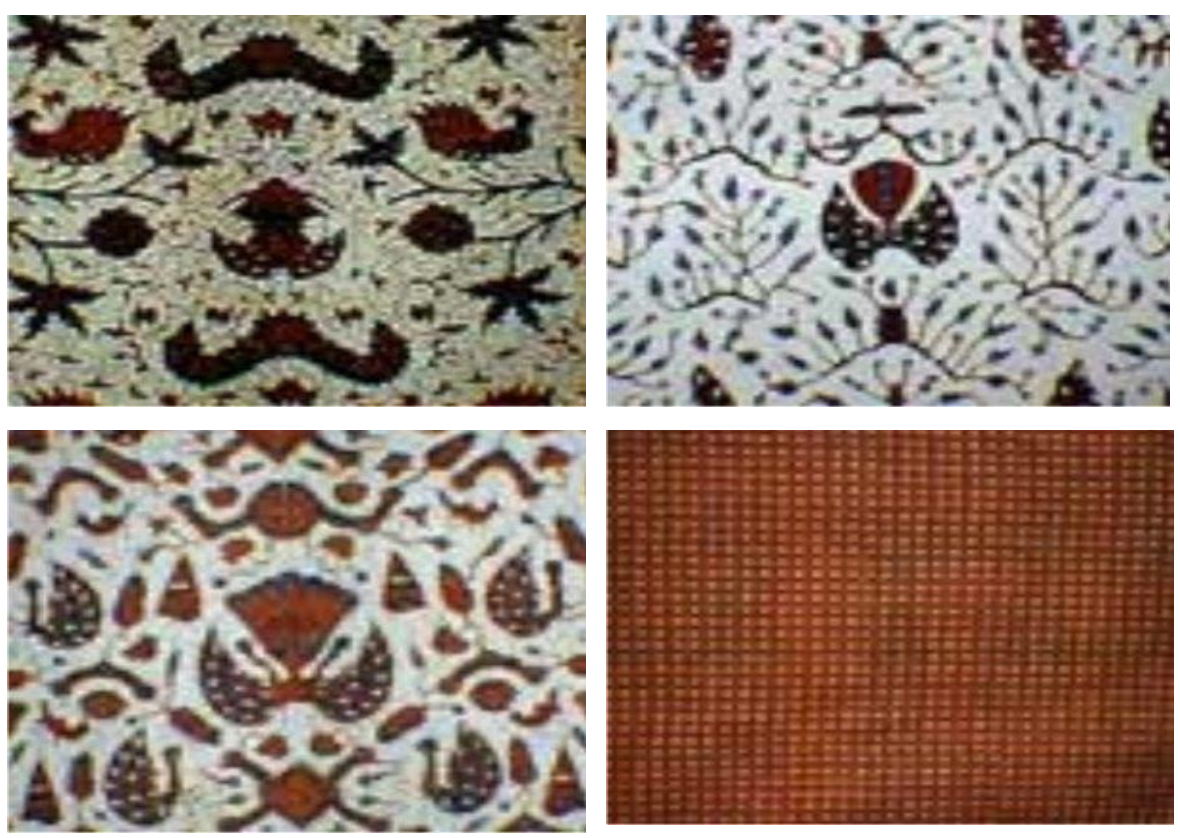

\section{Gambar 3 Motif Kain}

1) Wahyu tumurun, maknanya agar bayi yang akan lahir menjadi orang yang senantiasa mendekatkan diri kepada Tuhan Yang Maha Esa dan selalu mendapat petunjuk dan perlindungan dari-Nya;

2) Sido asih, maknanya agar bayi yang akan lahir menjadi orang yang selalu di cintai dan dikasihi oleh sesama serta mempunyai sifat belas kasih;

3) Sidomukti, maknanya agar bayi yang akan lahir menjadi orang yang mukti wibawa, yaitu berbahagia dan disegani karena kewibawaannya;

4) Truntum, maknanya agar keluhuran budi orangtuanya menurun (tumaruntum) pada sang bayi;

5) Sidoluhur, maknanya agar anak menjadi orang yang sopan dan berbudi pekerti luhur;

6) Parangkusumo, maknanya agar anak memiliki kecerdasan bagai tajamnya parang dan memiliki ketangkasan bagai parang yang sedang dimainkan pesilat tangguh. Diharapkan dapat: mikul dhuwur mendhem jero, artinya menjunjung harkat dan martabat orang tua serta mengharumkan nama baik keluarga;

7) Semen romo, maknanya agar anak memiliki rasa cinta kasih kepada sesama layaknya cinta kasih Rama dan Sinta pada rakyatnya;

8) Udan riris, maknanya agar anak dapat membuat situasi yang menyegarkan, enak dipandang, dan menyenangkan siapa saja yang bergaul dengannya;

9) Cakar ayam, maknanya agar anak pandai mencari rezeki bagai ayam yang mencari makan dengan cakarnya karena rasa tanggung jawab atas kehidupan anak-anaknya, sehingga kebutuhan hidupnya tercukupi, syukur bisa kaya dan berlebihan; 

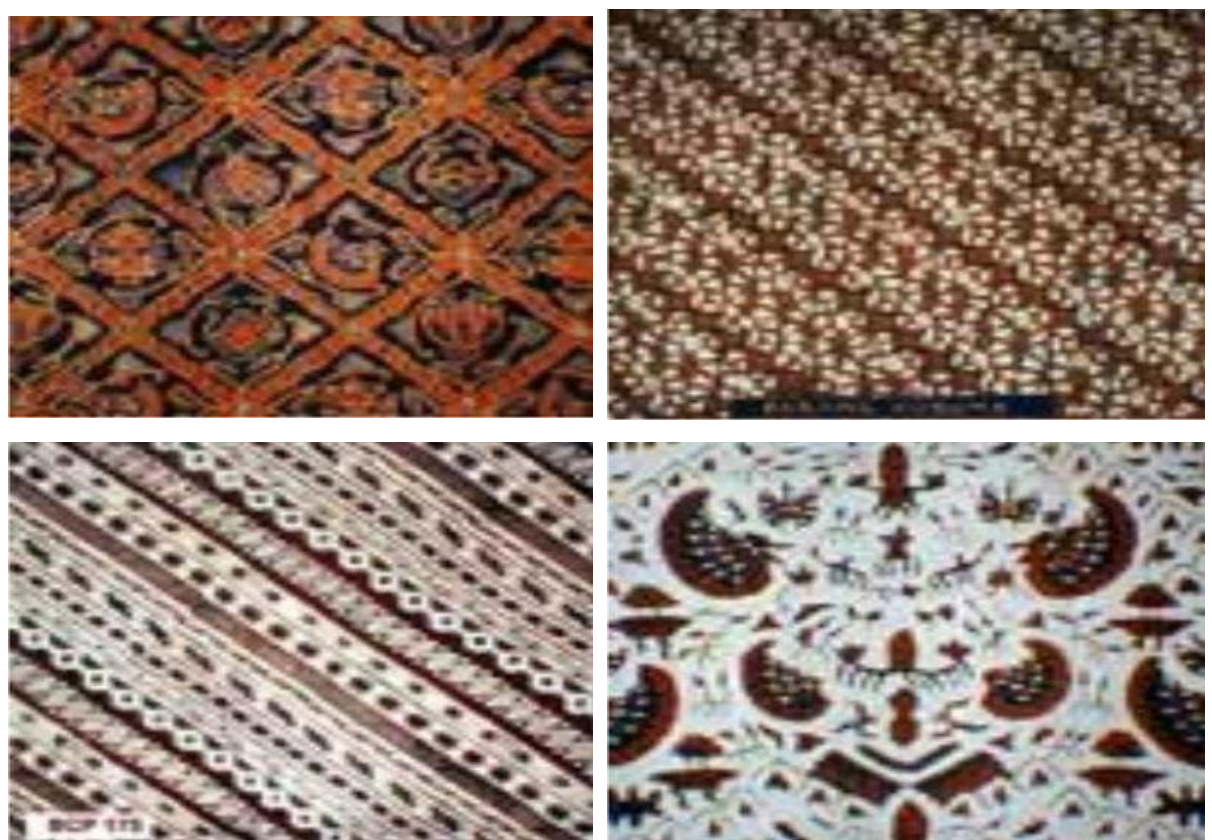

\section{Gambar 4 Motif Kain}

10) Grompol, maknanya semoga keluarga tetap bersatu, tidak bercerai-berai akibat ketidakharmonisan keuarga (nggrompol: berkumpul);

11) Lasem, bermotif garis vertikal, bermakna semoga anak senantiasa bertakwa pada Tuhan Yang Maha Esa;

12) Dringin, bermotif garis horisontal, bermakna semoga anak dapat bergaul, bermasyarakat, dan berguna antarsesama.
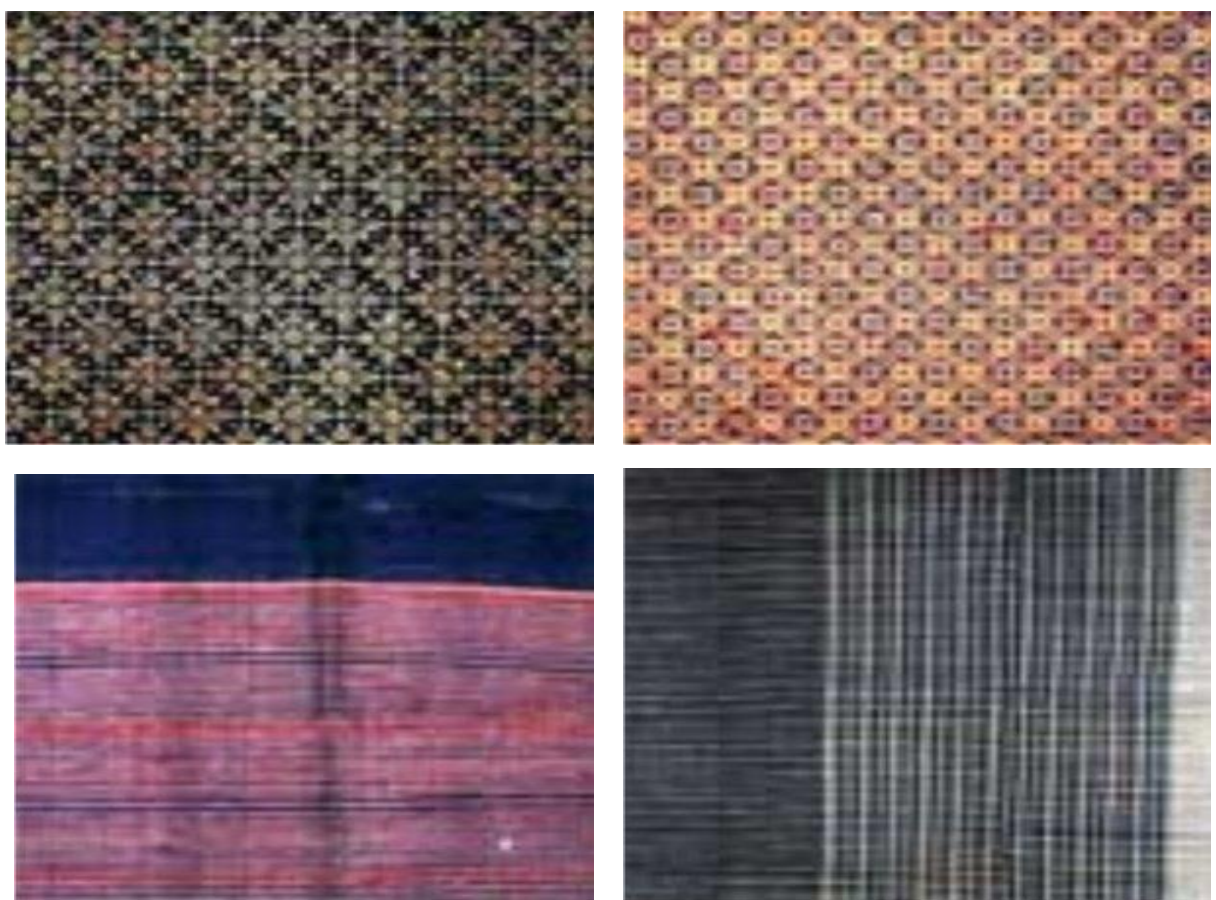

\section{Gambar 5 Motif Kain}


Mori dipakai sebagai busana dasar sebelum berganti-ganti nyamping, dengan maksud bahwa segala perilaku calon ibu senantiasa dilambari dengan hati bersih. Jika suatu saat keluarga tersebut bahagia sejahtera dengan berbagai fasilitas atau kekayaan atau memiliki kedudukan maka hatinya tetap bersih tidak sombong atau congkak, serta senantiasa bertakwa kepada Tuhan.
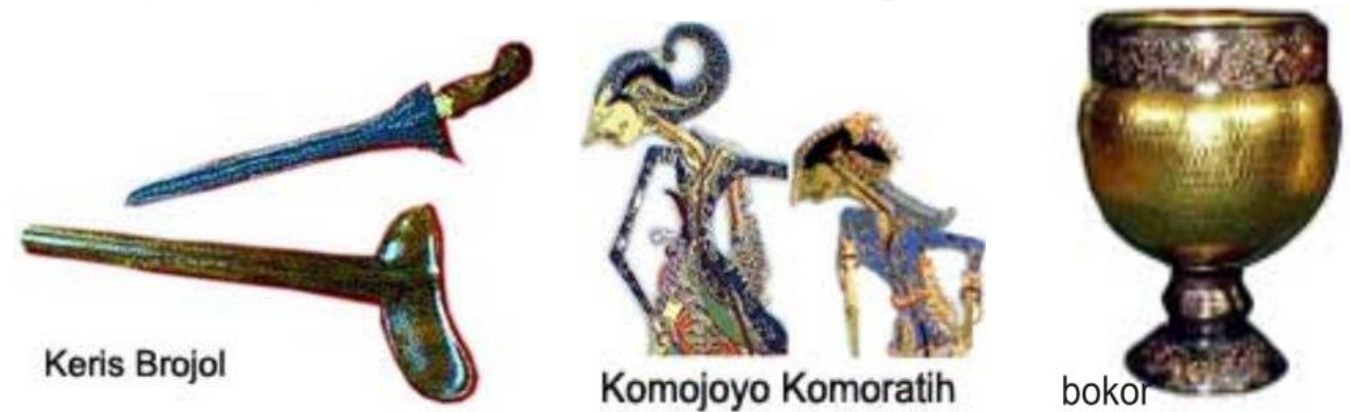

\section{Gambar 6 Keris Brojol, Komojoyo Komoratih, dan Bokor}

Pemutusan Lawe atau janur kuning yang dilingkarkan di perut calon ibu, dilakukan calon ayah menggunakan keris Brojol yang ujungnya diberi rempah kunir, dengan maksud agar bayi dalam kandungan akan lahir dengan mudah. Calon nenek dari pihak calon ibu, menggendong kelapa gading dengan ditemani oleh ibu besan. Sebelumnya kelapa gading diteroboskan dari atas ke dalam kain yang dipakai calon ibu lewat perut, terus ke bawah, diterima (ditampani) oleh calon nenek, maknanya agar bayi dapat lahir dengan mudah, tanpa kesulitan. Calon ayah memecah kelapa, dengan memilih salah satu kelapa gading yang sudah digambari Kamajaya dan Kamaratih atau Harjuna dan Wara Sembodro atau Srikandi. Upacara memilih nasi kuning yang diletak di dalam takir sang suami. Setelah itu dilanjutkan dengan upacara jual dawet dan rujak, pembayaran dengan pecahan genting (kreweng), yang dibentuk bulat, seolah-olah seperti uang logam. Hasil penjualan dikumpulkan dalam kuali yang terbuat dari tanah liat. Kwali yang berisi uang kreweng dipecah di depan pintu. Maknanya agar anak yang dilahirkan banyak mendapat rejeki, dapat menghidupi keluarganya dan banyak amal.

Hidangan sebagai ucapan syukur kepada Tuhan Yang Maha Esa, yang disediakan dalam upacara tingkepan yakni: (1) tujuh macam bubur, termasuk bubur procot; (2) tumpeng kuat, maknanya bayi yang akan dilahirkan nanti sehat dan kuat (tumpeng dengan urab-urab tanpa cabe, telur ayam rebus dan lauk yang dihias); (3) jajan pasar, syaratnya harus beli di pasar (kue,buah,makanan kecil); (4) rujak buah-buahan tujuh macam, dihidangkan sebaik-baiknya supaya rujaknya enak, bermakna anak yang dilahirkan menyenangkan dalam keluarga; (5) dawet, supaya menyegarkan; (6) keleman, semacam umbi-umbian, sebanyak tujuh macam; dan (7) sajen medikingan, dibuat untuk kelahiran setelah kelahiran anak pertama dan seterusnya, macamnya: nasi kuning berbentuk kerucut; enten-enten yaitu kelapa yang telah diparut dicampur dengan gula kelapa dimasak sampai kering; nasi loyang, nasi kuning yang direndam dalam air,kemudian dikukus kembali dan diberi kelapa yang telah diparut; bubur procot yaitu tepung beras, 
santan secukupnya, gula kelapa dimasak secara utuh, dimasukkan ke dalam periuk untuk dimasak bersama-sama.

b. Kronologis Upacara Tingkepan

1) Waktu Pelaksanaan

Dilaksanakan antara pukul 9.00 sampai dengan pukul 11.00. Calon ibu mandi dan cuci rambut yang bersih, mencerminkan kemauan yang suci dan bersih. Kira-kira pukul 15.00-16.00 upacara tingkepan dapat dimulai, menurut kepercayaan pada jam-jam itulah bidadari turun mandi. undangan sebaiknya dicantumkan lebih awal pukul 14.30.

2) Hari Pelaksanaan

Biasanya dipilih hari Rabu atau hari Sabtu, tanggal 14 dan 15 penanggalan Jawa, menurut kepercayaan agar bayi yang dilahirkan memiliki cahaya yang bersinar, dan menjadi anak yang cerdas.

3) Pelaksana yang menyirami/memandikan

Para ibu yang jumlahnya tujuh orang, yang terdiri dari sesepuh terdekat. Upacara dipimpin oleh ibu yang sudah berpengalaman.

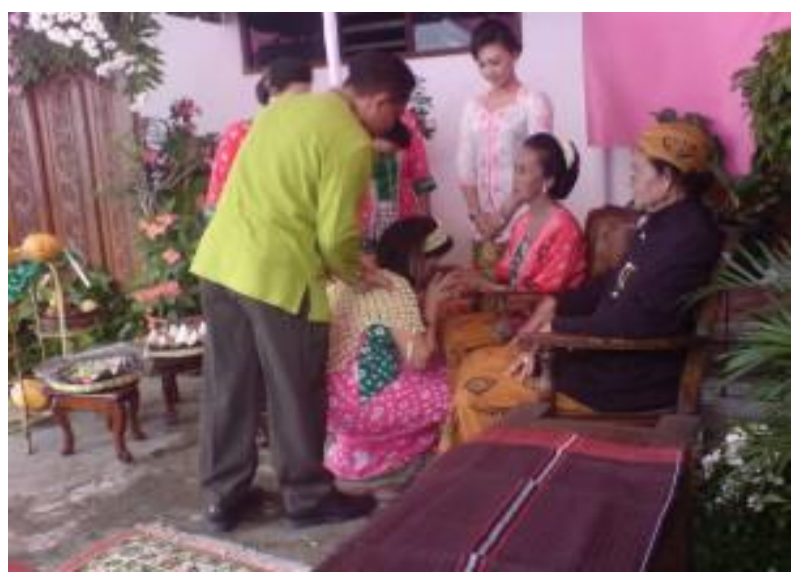

Gambar 7 Sungkem kepada Calon Nenek

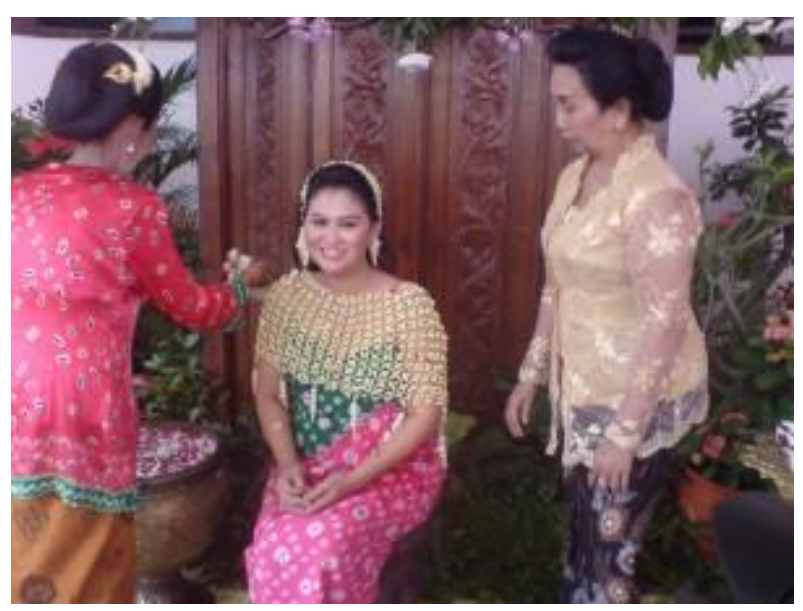

Gambar 8 Siraman 
4) Perlengkapan yang diperlukan

Satu meja yang ditutup dengan kain putih bersih, di atasnya ditutup lagi dengan bangun tolak, kain sindur, kain lurik, yuyu sekandang, mayang mekak atau letrek, daun dadap srep, daun kluwih, daun alang-alang. Bahan bahan tersebut untuk lambaran waktu siraman.

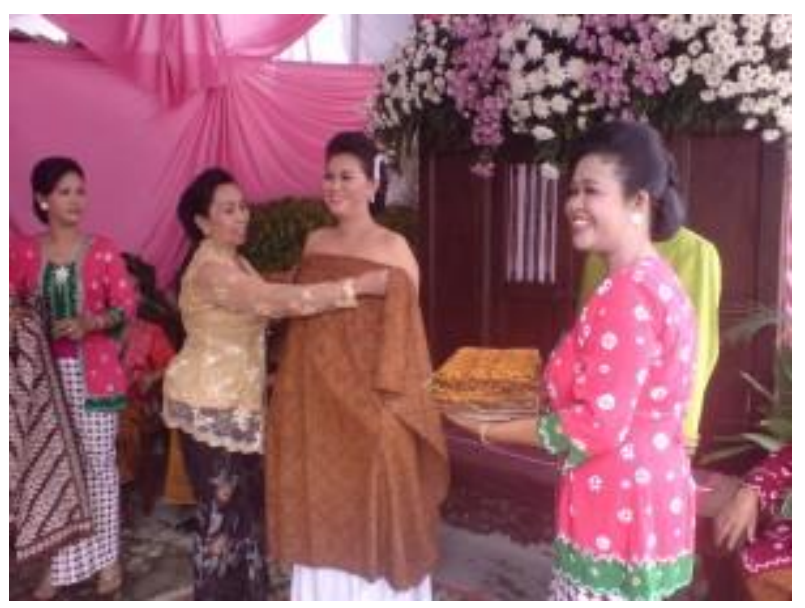

\section{Gambar 9 Mematut Kain}
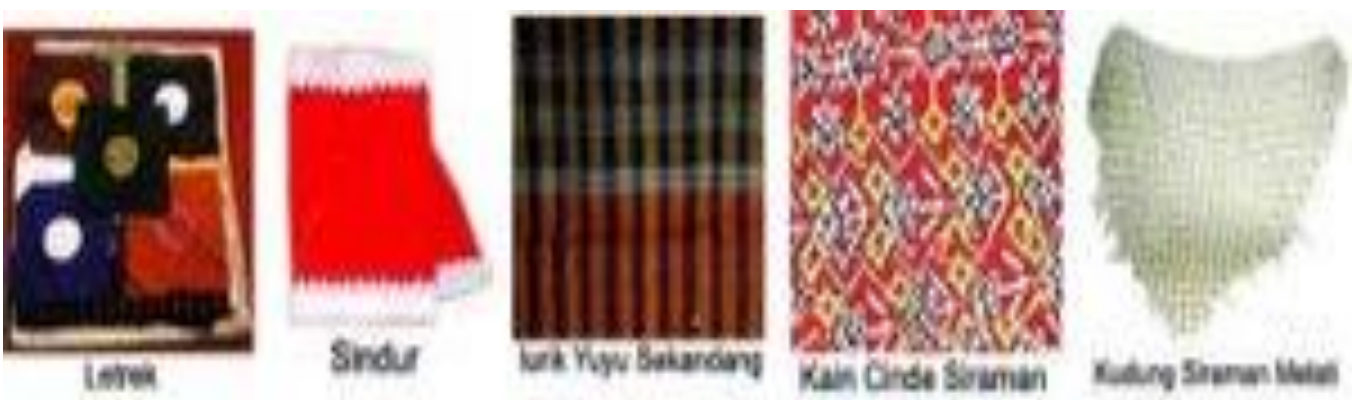

\section{Gambar 10 Perlengkapan Tingkepan}

\section{5) Perlengkapan lainnya}

Bokor di isi air tujuh mata air dan kembang setaman untuk siraman. Batok (tempurung) sebagai gayung siraman (Ciduk). Boreh untuk mengosok badan penganti sabun. Kendi dipergunakan untuk memandikan paling akhir. Dua anduk kecil untuk menyeka dan mengeringkan badan setelah siraman. Dua setengah meter kain mori dipergunakan setelah selesai siraman. Sebutir telur ayam kampung dibungkus plastik. Dua cengkir gading yang digambari Kamajaya dan Kamaratih atau Arjuna dan Dewi Wara Sembodro. Busana Nyamping aneka ragam, dua meter lawe atau janur kuning. Baju dalam dan nampan untuk tempat kebaya dan tujuh nyamping dan stagen diatur rapi. Perlengkapan kejawen kakung dengan satu pasang kain truntum. Calon ayah dan ibu berpakain komplet kejawen, calon ibu dengan rambut terurai dan tanpa perhiasan.

\section{6) Selamatan Tingkepan}

Tumpeng Robyong dengan kuluban, telur ayam rebus, ikan asin yang digoreng, peyon atau pleret adonan kue/nogosari diberi warna-warni dibungkus 
plastik, kemudian dikukus. Satu pasang ayam bekakah(ingkung panggang). Ketupat lepet (ketupat dibelah diisi bumbu, bermacam buah-buahan, jajan pasar dan pala pendem (ubi-ubian). Arang-arang kembang satu gelas ketan hitam goring sangan.

Bubur putih satu piring, bubur merah satu piring, bubur sengkala satu piring, bubur procot/ketan procot, ketan dikaru santan, setelah masak dibungkus dengan daun/janur kuning yang memanjang tidak boleh dipotong atau dibiting. Nasi kuning ditaburi telur dadar, ikan teri goring, ayam, rempah, dawet ayu (cendol, santan dengan gula jawa). Rujak Manis terdiri dari tujuh macam buah. Perlengkapan selamatan tingkepan di atas, dibacakan doa untuk keselamatan seluruh keluarga. Kemudian dinikmati bersama tamu undangan dengan minum dawet ayu, sebagai penutup.

\section{Pandangan Islam tentang Selamatan Tujuh Bulanan (Tingkepan)}

Umat Islam Indonesia di Jawa maupun di pulau selainnya, saat menyambut putera pertama ternyata masih melakukan ritual-ritual yang tidak ada perintahnya dari Nabi Muhammad SAW. Acara itu adalah neloni (selamatan ketika kehamilan berusia tiga bulan), mitoni (saat berusia tujuh bulan), dan juga tingkepan. Sebagian melakukannya ketiga-tiganya, ada pula yang melakukan acara mitoni dan tingkepan, ada pula yang melakukan tingkepan saja karena mitoni dianggap sama dengan tingkepan. Sebagian orang Jawa mempercayai bahwa mitoni atau selamatan tujuh bulanan, dilakukan setelah kehamilan seorang ibu genap usia 7 bulan atau lebih.

Mitoni dan tingkepan dilaksanakan saat kehamilan berusia tidak boleh kurang dari 7 bulan. Karena tidak ada neptu atau weton (hari masehi + hari Jawa) yang dijadikan patokan, maka hari selasa atau sabtu yang digunakan. Tujuan mitoni atau tingkepan agar supaya ibu dan janin selalu dijaga dalam kesejahteraan dan keselamatan (wilujeng, santosa, jatmika, rahayu). Keputusan Muktamar Nahdlatul Ulama ke-5 di Pekalongan, tanggal 7 September 1930 (halaman 58) disebutkan pernyataan dan jawaban:

- Pertanyaan: Bagaimana hukumnya melempar kendi yang penuh air hingga pecah pada waktu orang-orang yang menghadiri Upacara Peringatan Bulan Ketujuh dari umur kandungan pulang dengan membaca shalawat bersamasama, dan dengan harapan supaya mudah kelahiran anak kelak. Apakah hal tersebut hukumnya haram karena termasuk membuang-buang uang (tabzir)?

- Jawab: Ya, perbuatan tersebut hukumnya haram karena termasuk tabzir.

Keputusan Muktamar Nahdlatul Ulama ke-7 di Bandung, tanggal 9 Agustus 1932, menyebutkan menanam ari-ari (masyimah/tembuni) hukumnya sunnah. Adapun menyalakan lilin (lampu) dan menaburkan bunga-bunga di atasnya itu hukumnya haram, karena membuang-buang harta (tabzir) yang tidak ada manfaatnya. Budaya mitoni masih sangat lekat dengan budaya Jawa dan merupakan salah satu budaya yang paling populer di kalangan masyarakat Jawa. Mayoritas masyarakat menganggap budaya mitoni merupakan tradisi yang benarbenar sakral dan pantang di lewatkan, hal tersebut mengingat paham tentang ketakutan mereka akan ketidaksempurnaan lahir dari bayi bila tidak dipitoni. 
Sebenarnya bahkan ditakutkan kalau yang gaib merasa di tinggalkan dan bayi tersebut dapat saja di kutuk untuk dijadikan peringatan nantinya. Hal lainnya tentu saja untuk meneruskan budaya yang telah lama turun temurun dari nenek moyang, sehingga sering kali di beberapa daerah, keluarga yang tidak melakukan akan di cela warga. Peninggalan dari jaman Hindu ini sudah mendarah daging di masyarakat. Beberapa diantaranya menyebutkan bahwa ajaran ini juga mengandung nilai-nilai dan merupakan salah satu wujud ibadah islami yaitu untuk minta selamat pada yang kuasa melalui ibadah berbentuk seremonial yang kerap kali memang disisipi nuansa islami (sholawatan misalnya).

Meski demikian, tidak sepenuhnya masyarakat berpendapat sama dan memberi tanggapan positif akan paham tersebut. Justru paham inilah yang seringkali menimbulkan protes keras dari beberapa pihak. Mereka menyebutkan bahwa paham tersebut sama sekali bukan ajaran Islam dan melenceng jauh dari nilai-nilai agama Islam, bahkan diantaranya menganggap acara tersebut haram dilakukan karena dianggap melencengkan agama (bid'ah).

Demikian juga ketika anak dilahirkan mereka melakukan amalan yang sama dengan menanam ari-ari di kanan atau kiri pintu utama rumah dan meneranginya selama tiga bulan. Selamatan kehamilan, seperti 3 bulanan atau 7 bulanan (Nujuh Bulanan), tidak ada dalam ajaran Islam. Itu termasuk perkara baru dalam agama. Dan semua perkara baru dalam agama adalah bid'ah, dan semua bid'ah merupakan kesesatan. Rasulullah SAW bersabda:

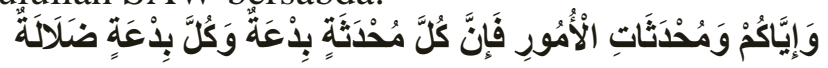

Artinya: Jauhilah semua perkara baru (dalam agama), karena semua perkara baru (dalam agama) adalah bid'ah, dan semua bid'ah merupakan kesesatan (HR Abu Dawud, no. 4607; Tirmidzi, 2676; Ad Darimi; Ahmad; dan lainnya dari Al 'Irbadh bin Sariyah).

Kemudian jika selamatan kehamilan tersebut disertai dengan keyakinan akan membawa keselamatan dan kebaikan dan sebaliknya jika tidak dilakukan akan menyebabkan bencana atau keburukan, maka keyakinan seperti itu merupakan kemusyrikan. Karena sesungguhnya keselamatan dan bencana itu hanya di tangan Allah semata. Allah berfirman:

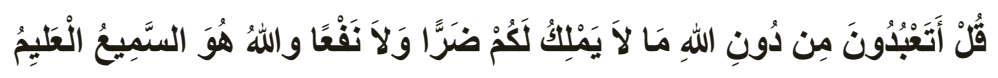

Artinya: Katakanlah "mengapa kamu menyembah selain daripada Allah, sesuatu yang tidak dapat memberi mudharat kepadamu dan tidak (pula) memberi manfaat? Dan Allah-lah Yang Maha Mendengar lagi Maha Mengetahui (QS Al Maidah: 76).

\section{Kesimpulan}

Mitoni merupakan warisan budaya yang telah lama ada dan mendarah daging di masyarakat Jawa. Upacara-upacara yang dilakukan dalam masa kehamilan, yaitu: siraman, memasukkan telor ayam kampung ke dalam kain calon ibu oleh sang suami, ganti busana, memasukkan kelapa gading muda, memutus lawe/lilitan benang/janur, memecahkan periuk dan gayung, minum jamu sorongan, dan nyolong endhog; pada hakikatnya ialah upacara peralihan yang 
dipercaya sebagai sarana untuk menghilangkan petaka, yaitu semacam inisiasi yang menunjukkan bahwa upacara-upacara itu merupakan penghayatan unsurunsur kepercayaan lama. Selain itu, terdapat suatu aspek solidaritas primordial terutama adalah adat istiadat yang secara turun temurun dilestarikan oleh kelompok sosialnya. Mengabaikan adat istiadat akan mengakibatkan celaan dan nama buruk bagi keluarga yang bersangkutan di mata kelompok sosial masyarakatnya.

Kebudayaan merupakan kekayaan bangsa yang patut untuk dijaga dan di lestarikan, tentunya begitu pula dengan mitoni. Namun sebagai penganut Islam yang baik sudah semestinya pula masyarakat dapat menjadikan agama bukan hanya sebagai ucapan lidah, namun juga alat seleksi kebudayaan mana yang patut untuk dilakukan dan tidak bertentangan dengan ajaran yang diyakini. Kebudayaan memang kerap berhubungan dengan nilai-nilai yang bersifat religius, namun bukan berarti harus di kait-kaitkan dengan religi lain yang ada.

Paling tidak dari tradisi ini terkandung nilai-nilai filosofis dalam kehidupan, yakni: pertama melestarikan tradisi leluhur dalam rangka memohon keselamatan. Hal ini tentunya memiliki nilai yang istimewa karena melestarikan budaya yang baik merupakan kekayaan khazanah dalam kehidupan. Dalam qaedah ushul fikih disebutkan "al-muhafazhah 'ala qadim ash-shalih, wal ahdzu bil jadidi al-ashlih", melestarikan tradisi lama yang baik, dan mengambil tradisi baru yang lebih baik. Kedua menjaga keseimbangan, keselarasan, kebahagiaan, dan keselamatan (slamet, ora ono apo-apo). Ketiga, karakter masyarakat Jawa yang berpikir asosiatif. Keempat, proses penyucian diri (tazkiyatun nafsi) ketika memohon kepada Allah SWT. 


\section{DAFTAR RUJUKAN}

Ainun, B. J. H. 1997. Peran Wanita dalam Menciptakan Keluarga Sakinah dalam Membincangkan Feminisme: Refleksi Muslimah atas Peran Sosial Wanita. Bandung: Pustaka Hidayah.

Al-Bâni, Muhammad Nâshir al-Dîn. Tanpa tahun. Shahîh Sunan Nasâ'i. Purbalingga: Pustaka Azzam.

Al-Qur'an dan Terjemahnya. 2004. Jakarta: Kementerian Agama Islam Republik Indonesia.

Asqalâni, Ibn Hajar. Tanpa tahun. Fath al-Bârî. Penjelasan Kitab Shahih alBukhari. Purbalingga: Pustaka Azzam.

Gunasasmita. 2009. Kitab Primbon Jawa Serbaguna. Yogyakarta: Soemodidjaja Mahadewa.

LTN NU Jawa Timur. 2005. Ahkamul Fuqaha: Solusi Problematika Aktual Hukum Islam, Keputusan Muktamar Munas, dan Konbes Nahdlatul Ulama (1926- 1999 M). Surabaya: Kerjasama LTN NU Jawa Timur dan Diantama Surabaya.

Romana, T. 2012. Mengenal Tradisi Nusantara Seputar Kehamilan (Online). (http://health.kompas.com/read/2012/09/10/15145533/Mengenal.Tradisi.N usantara.Seputar.Kehamilan, diakses 27 Desember 2012).

Sugeng, W. 2011. Mitoni Ritual Budaya yang Hampir Punah (Online). (http://sosbud.kompasiana.com/2011/03/07/ mitoni-ritual-budaya-yanghampir-punah/, diakses 27 Desember 2012).

Tjakraningrat, K. P. 1980. Harya Atassadhur Adimmakna. Yogyakarta: Soemodidjaja Mahadewa. 